\title{
PERANAN ABU SEKAM PADI UNTUK MENGURANGI POROSITAS CONBLOCK RINGAN SEKAM PADI
}

\author{
The Role of Rice Husk Ash to Reduce Porosity of Lightweight Rice Husk - Conblock
}

Bakri西

Lab. Pemanfaatan dan Pengolahan Hasil Hutan, Fakultas Kehutanan Universitas Hasanuddin, Jl. Perintis Kemerdekaan Km. 10 Tamalanrea, Makassar 90245

\begin{abstract}
This research aimed to determine the role of rice husk ash as pozzolanic material in reducing porosity of lightweight rice husk-conblock. Rice husk ash was obtained by burning rice husk conventionally in kiln drum and subsequently followed by burning in furnace of 1400 Barnsted Thermolyne Type at temperature $600{ }^{\circ} \mathrm{C}$ for 2 hours. Sample test preparation and procedure of porosity was adopted from ASTM C 140 . Rice husk ash significantly reduced the porosity at all treatment combinations of rice husk ash percentage, but the lower porosity (31\%) obtained by using rice husk ash of $20 \%$.
\end{abstract}

Key words: rick husk, rice husk ash, lightweight conblock, porosity

\section{PENDAHULUAN}

Sekam padi merupakan bahan berlignosellulosa seperti biomassa kayu sehingga dapat digunakan sebagai agregat komposit semen. Selain dapat digunakan sebagai agregat, sekam padi dapat pula dikembangkan sebagai bahan baku untuk menghasilkan abu pozzolan yang dikenal di dunia sebagai abu sekam padi (rice husk ask).

Agregat ringan yang digunakan untuk membuat komposit semen ringan (lightweight cement composite) sangat sesuai digunakan dalam pembuatan conblock siap pakai. Girard (2006) mengemukakan bahwa conblock ringan sebaiknya digunakan untuk industri konstruksi dimana pengurangan berat merupakan faktor penting. yang harus dipertimbangkan. Tujuan penggunaan komposit semen ringan dalam bentuk conblock ringan atau concrete masonry unit ringan lainnya pada komponen struktural pada dasarnya adalah untuk mengurangi beban mati struktur sehingga para perancang struktur dapat mengurangi ukuran komponen struktural yang sengaja dirancang untuk

\footnotetext{
Diterima: 10 Agustus 2011; Disetujui: 24 November 2011

$\square$ Penulis korespondensi (corresponding author): bakribakri10@yahoo.com
}

menahan atau memikul beban seperti kolom, sloft, balok, dan elemen pelat lainnya. Conblock atau yang biasa pula disebut sebagai concrete masonry unit (CMU) merupakan salah salah jenis produk dari komposit semen yang digunakan sebagai komponen non struktural dengan tujuan utama bukan untuk menahan atau memikul beban dalam konstruksi tetapi sebagai pelindung atau pemisah ruangan. Dinding dan partisi merupakan komponen non struktural yang paling banyak menggunakan produk conblock pada sektor konstruksi. ASTM C 90 mengklasifikasikan concrete masonry unit atau conblock dalam 3 kelas yaitu ringan, sedang, dan normal berdasarkan kerapatan kering tanur masing masing sebesar kurang dari $1.780 \mathrm{~kg} \mathrm{~m}^{-3}, 1.780$ $-2.000 \mathrm{~kg} \mathrm{~m}^{-3}$, dan lebih besar dari $2.000 \mathrm{~kg} \mathrm{~m}^{-3}$ (NCMA, 2007).

Namun demikian karena mengandung silika tinggi, sekam padi tidak tahan terhadap kondisi alkalin dan asam sehingga jika bercampur dengan semen potensil menghasilkan reaksi alkali silika yang dapat menyebabkan keretakan. Semen Portland mengandung ion alkali $\mathrm{Na}^{+}$dan $\mathrm{K}^{+}$dalam sodium oksida $\left(\mathrm{Na}_{2} \mathrm{O}\right)$ dan potasium oksida $\left(\mathrm{K}_{2} \mathrm{O}\right)$ dengan persentase yang sangat kecil yaitu antara 0,2-1,1\%. Namun demikian ion-ion alkali ini akan terkonsentrasi pada larutan dalam pori pasta 
semen ketika bergabung dengan ion hidroksil $\left(\mathrm{OH}^{-}\right)$ sehingga dapat menaikkan $\mathrm{pH}$ larutan dalam pori pasta semen menjadi 13-14 (Bertolini et al., 2004). Jika campuran pasta semen mengandung agregat reaktif yaitu agregat yang memiliki kandungan silika maka senyawa dalam larutan alkali akan bereaksi dengan silika yang disebut sebagai reaksi alkali silika (ASR) (Kerenidis, 2007). ASR yang terjadi akan menghasilkan gel alkali silika dan jika gel ini menyerap air maka akan terjadi pengembangan yang mengakibatkan pasta semen retak (Freitag et al., 2003).

Reaksi alkali silika pada komposit semen dapat diatasi dengan mengganti sebagian semen dengan bahan yang mengandung pozzolan atau bahan yang mengandung silika tinggi. Bahan yang mengandung pozzolan tinggi ini biasa disebut sebagai supplementing cementitious material (SCM) atau pengganti sebagian semen. Gastaldini et al. (2007) mengemukakan bahwa beberapa hasil ikutan industri dan pertanian seperti slag, fly ash, dan rice husk ash (abu sekam padi) ternyata merupakan polutan potensil yang dapat digunakan sebagai bahan pengganti atau bahan tambahan pada semen. Penggunaan bahan pengganti sebagian semen (SCM) melalui komposisi campuran yang inovatif akan mengurangi jumlah semen yang digunakan sehingga secara ekologis dapat mengurangi emisi gas-gas rumah kaca dan penggunaan komsumsi energi fosil bumi pada industri semen (Naik, 2005).

Pengendalian ASR dapat dilakukan dengan cara (1) mengurangi pH larutan dalam pori, (2) mengurangi konsentrasi ion alkali metal bebas (ion $\mathrm{Na}^{+}$dan $\mathrm{K}^{+}$), dan (3) mengurangi permeabilitas pasta semen (Lee, 2005). Penggunaan SCM dapat dilakukan untuk memenuhi ketiga cara pengendalian ASR tersebut. Peranan bahan SCM yaitu akan menghasilkan kalsium silikat hidrat (CSH) sekunder pada proses hidrasi semen yang dapat memperkecil ukuran pori sehingga porositas dan permeabilitas pasta semen berkurang. Penyerapan air yang besar pada campuran pasta semen dapat diatasi dengan mengurangi porositasnya sehingga ASR dapat dikendalikan.

Abu sekam padi yang dihasilkan dari pembakaran sekam padi pada suhu $400-500{ }^{\circ} \mathrm{C}$ akan menjadi silika amorphous dan pada suhu lebih besar dari $1.000{ }^{\circ} \mathrm{C}$ akan menjadi silika kristalin (Shinohara \& Kohyama, 2004). Kandungan silika pada abu sekam padi berkisar antara 92-
$95 \%$, sangat porous dan ringan, dan memiliki luas permukaan yang sangat besar (DTI, 2003). Abu sekam padi memiliki aktivitas pozzolanic yang sangat tinggi sehingga potensil digunakan sebagai SCM.

Penggunaan abu sekam padi dengan kombinasi campuran yang sesuai pada semen akan menghasilkan komposit semen yang lebih baik (Singh et al., 2002). Abu sekam padi telah digunakan sebagai bahan pozzolan reaktif yang sangat tinggi untuk meningkatkan mikrostruktur pada daerah transisi interfase antara pasta semen dan agregat. Abu sekam padi telah digunakan sebagai SCM dalam pembuatan beton yang memiliki kekuatan tinggi dan permeabilitas rendah pada jembatan, bangunan dermaga, dan bangunan pembangkit tenaga nuklir karena abu sekam padi dapat meningkatkan reaksi pozzolan untuk pembentukan kalsium silikat hidrat (Dakroury \& Gasser, 2008).

\section{BAHAN DAN METODE}

Bahan penelitian terdiri atas semen Portland tipe I, kapur, sekam padi, dan air destilasi yang tersedia di Makassar. Abu pozzolan sekam padi dibuat seperti yang dilakukan oleh Harsono (2002) dan Ganesan et al. (2008). Instrumen penelitian terdiri atas gelas ukur, timbangan digital, thermometer, hygrometer, caliper, molder kubus $50 \times 50 \times 50 \mathrm{~mm}$, baskom, ember, kantung plastik, steamer, drum ayakan, mixer, tanur, dan komputer.

Penelitian yang dilaksanakan merupakan penelitian eksperimental yang menggunakan percobaan faktorial. Rancangan dasar yang digunakan dalam percobaan faktorial adalah rancangan acak lengkap (RAL). Rancangan acak lengkap ini terdiri atas 3 faktor sebagai variabel bebas yaitu faktor abu sekam padi (A) yaitu persentase berat abu sekam padi terhadap berat matriks (semen + kapur + abu sekam padi), faktor sekam padi (B) yaitu persentase berat sekam padi terhadap berat matriks (semen + kapur + abu sekam padi), dan faktor persentase perbandingan semen dan kapur (C) yaitu rasio berat semen dan kapur terhadap berat (semen + kapur). Faktor A terdiri atas 4 taraf yaitu $0 \%(\mathrm{~A} 0), 20 \%(\mathrm{~A} 1), 30 \%(\mathrm{~A} 2)$, dan $40 \%$ (A3), faktor $B$ terdiri atas 2 taraf yaitu $30 \%$ (B1) dan $40 \%$ (B2), dan faktor $\mathrm{C}$ terdiri atas 3 taraf yaitu $100: 0$ (C1), $75: 25$ (C2), dan $50: 50$ (C3).

Prosedur pembuatan dan pengujian contoh uji porositas merujuk pada ASTM C 140 dengan 


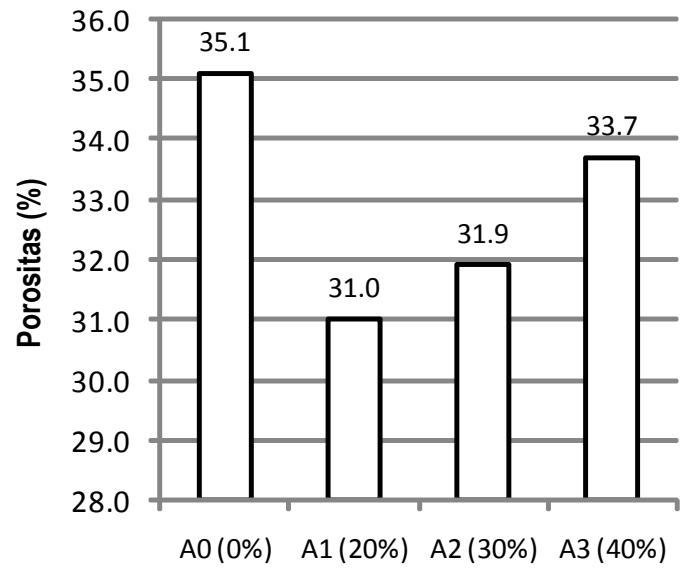

Persentasi Abu Sekam Padi (\%)

Gambar 1. Pengaruh faktor A (Persentase abu sekam padi) terhadap porositas

berbagai penyesuaian seperti ukuran contoh uji dan pelaksanaan curing. Pembuatan contoh uji dilakukan dengan cara memasukkan masing-masing campuran berdasarkan kombinasi percobaan ke dalam molder kubus yang memiliki ukuran $50 \times 50 \mathrm{x}$ $50 \mathrm{~mm}$. Jumlah ulangan yang dilakukan pada setiap kombinasi campuran adalah 3 buah. Campuran yang telah dimasukkan ke dalam molder disimpan selama 1 hari kemudian dikeluarkan dari molder dan di simpan pada suhu ruangan selama 7 hari curing period. Contoh uji dicelup selama 24 jam dan setelah itu ditimbang dalam keadaan tergantung untuk mendapatkan berat contoh uji dalam air (Wi). Contoh uji dikeluarkan dari air kemudian dibiarkan selama 1 menit dan permukaannnya dilap. Contoh uji kemudian ditimbang untuk mendapatkan berat contoh uji jenuh air (Ws). Contoh uji kemudian disimpan pada suhu $24{ }^{\circ} \mathrm{C}$ selama 21 hari curing period lanjutan. Contoh uji ditimbang setelah 21 hari curing period lanjutan sebagai berat contoh uji kering udara (We). Contoh uji kemudian dimasukkan ke dalam tanur pada suhu $100-115{ }^{\circ} \mathrm{C}$ selama 24 jam. Contoh uji dikeluarkan dalam tanur kemudian

Tabel 1. Uji BNJ pengaruh faktor A (persentase abu sekam padi) terhadap porositas (\%)

\begin{tabular}{ccc}
\hline $\mathrm{A}(\%)$ & $\begin{array}{c}\text { porositas rata- } \\
\text { rata }(\%)\end{array}$ & BNJ 0,05 $=1,8$ \\
\hline 20 & 31,0 & $\mathrm{a}$ \\
30 & 31,9 & $\mathrm{a}$ \\
40 & 33,7 & $\mathrm{~b}$ \\
0 & 35,1 & $\mathrm{~b}$ \\
\hline keterangan: huruf yang & sama menunjukkan tidak & ada \\
& pengaruh yang signifikan pada taraf $5 \%$
\end{tabular}

ditimbang untuk mendapatkan berat contoh uji kering tanur (Wd). Porositas dihitung berdasarkan rumus : $\mathrm{P}(\%)=\{(\mathrm{Ws}-\mathrm{Wd}) /(\mathrm{Ws}-\mathrm{Wi})\} \times 100$.

\section{HASIL DAN PEMBAHASAN}

Nilai hasil pengujian porositas contoh uji ratarata menunjukkan bahwa nilai porositas contoh uji rata-rata berkisar antara 27,5\% pada komposisi campuran A1B1C1 $\{(20: 30:(100: 0)\}$ sampai dengan $36,4 \%$ pada komposisi campuran A3B2C3 $\{(40: 40:(50: 50)\}$. Untuk mengetahui pengaruh faktor dan interaksi antar faktor terhadap porositas contoh uji maka dilakukan analisis keragaman. Hasil analisis keragaman menunjukkan bahwa masingmasing perlakuan pada faktor $A$ (persentase abu sekam padi), B (persentase sekam padi), dan C (perbandingan semen dan kapur) berpengaruh nyata terhadap porositas contoh uji. Sedangkan interaksi antar faktor perlakuan menunjukkan pengaruh yang tidak nyata terhadap porositas. Untuk mengetahui perbedaan pengaruh masing-masing faktor $A, B$, dan $\mathrm{C}$ maka dilakukan uji lanjut BNJ.

Nilai porositas contoh uji rata-rata sebagai akibat dari pengaruh faktor $A$ pada berbagai persentase abu sekam padi dapat dilihat pada Gambar 1. Gambar 1 menunjukkan nilai porositas contoh uji rata-rata karena pengaruh faktor $A$ (persentase abu sekam padi) masing-masing adalah 35,$1 ; 33,7 ; 31,9$ dan $31,0 \%$ yang terjadi pada persentase abu sekam padi A0 (0 \%), A3 (40\%), A2 (30\%), dan A1 (20 $\%)$. Gambar 1 menunjukkan pula bahwa porositas contoh uji pada semua komposisi campuran yang menggunakan abu sekam padi yaitu A3 (40\%), A2 (30\%), dan A1 (20\%) memiliki nilai yang lebih kecil dari komposisi campuran yang tidak menggunakan abu sekam padi $(0 \%)$. Hal ini membuktikan bahwa penggunaan abu sekam padi dapat menurunkan nilai porositas dengan nilai terendah yaitu $31,1 \%$ terjadi pada penambahan persentase $20 \%$ (A1).

Hasil uji BNJ pada Tabel 1 mengenai pengaruh faktor $A$ (persentase abu sekam padi) terhadap porositas menunjukkan bahwa nilai porositas contoh uji rata rata terendah sebesar $31,0 \%$ terjadi pada perlakuan persentase abu sekam padi $20 \%$ dan nilai porositas contoh uji rata rata tertinggi sebesar $35,1 \%$ terjadi pada perlakuan persentase abu sekam padi $0 \%$. Tabel 1 menunjukkan pula bahwa perlakuan persentase abu sekam padi $20 \%$ berbeda nyata dengan perlakuan persentase abu sekam padi 40 dan $0 \%$ dan perlakuan persentase abu sekam padi 
$30 \%$ berbeda nyata dengan perlakuan persentase abu sekam padi $0 \%$.

Perbedaan nilai porositas oleh faktor $A$ (persentase abu sekam padi) dapat dijelaskan berdasarkan pembentukan pori selama proses hidrasi terjadi akibat penambahan abu sekam padi pada campuran semen. Berbagai macam pori dan rongga seperti pori gel, pori kapiler, rongga udara terperangkap, rongga gelembung udara, dan zona interfasial akan terbentuk selama proses hidrasi berlangsung. Pori gel terbentuk di antara gel-gel $\mathrm{CSH}$ sedangkan pori kapiler terbentuk di antara kumpulan atau agregasi gel $\mathrm{CSH}$. Pori kapiler merupakan jenis pori yang paling penting dalam transportasi massa dan permeabilitas dalam komposit semen. Jumlah air yang digunakan pada saat mencampur bahan-bahan komposit semen, derajat hidrasi, dan penggunaan bahan tambahan dalam campuran komposit semen mempengaruhi jumlah dan besarnya pori kapiler yang terbentuk.

Penggunaan abu sekam padi sebagai pengganti sebagian semen akan menghasilkan $\mathrm{CSH}$ sekunder yang berasal dari reaksi silika abu sekam padi dengan $\mathrm{CH}$ hasil hidrasi pasta campuran semen. CSH sekunder yang terbentuk mengendap pada bagian dalam pori kapiler, pori gel, dan zona interfasial yang menyebabkan ruang atau rongga pori menjadi lebih kecil sehingga nilai porositas menjadi berkurang. Penambahan abu sekam padi sebesar $20 \%$ menghasilkan nilai porositas sebesar $31,0 \%$ tetapi penambahan pada 30 dan $40 \%$ menyebabkan nilai porositas menjadi lebih besar kembali tetapi masih lebih kecil dibandingkan dengan nilai porositas pada contoh uji yang tidak menggunakan abu sekam padi (A0).

Penambahan abu sekam padi yang lebih banyak pada campuran semen mengakibatkan rasio $\mathrm{Ca} / \mathrm{Si}$ menjadi semakin tidak proporsional pada campuran semen. Semakin banyak abu sekam padi yang ditambahkan maka semakin tidak proporsional rasio $\mathrm{Ca} / \mathrm{Si}$ pada campuran semen. Reaksi proses hidrasi akan menjadi semakin lambat pada rasio $\mathrm{Ca} / \mathrm{Si}$ yang semakin tidak proporsional sehingga pembentukan $\mathrm{CSH}$ sekunder menjadi lebih lambat. Dengan demikian jumlah CSH yang dihasilkan dalam waktu yang sama menjadi lebih sedikit pada campuran semen yang mengandung persentase abu silika yang lebih banyak.

Nilai porositas juga dipengaruhi oleh semakin banyaknya pori yang tidak memiliki interkoneksitas dengan pori lainnya. Pori-pori yang tidak memiliki interkoneksitas dengan pori lainnya tidak diperhitungkan sebagai pori yang dapat menyerap air. Air yang terdapat pada pori ini merupakan air yang terjebak dan tidak akan melakukan pergerakan. Air dalam pori ini akan habis dengan sendirinya karena digunakan oleh C3S dan C2S yang belum terhidrasi selama proses hidrasi. Jika pori ini telah kosong maka air tidak akan masuk lagi ke dalam pori ini.

Pori yang tidak memiliki interkoneksitas umumnya adalah pori yang memiliki ukuran yang sangat kecil. CSH sekunder yang dihasilkan dari reaksi abu sekam padi dengan $\mathrm{CH}$ akan menutup pori ini sehingga air tidak akan bergerak ke dalam pori ini. Semakin banyak pori yang tidak memiliki interkoneksitas dengan pori lainnya maka semakin kecil nilai porositas contoh uji karena nilai porositas hanya ditentukan oleh pori yang dapat dilalui oleh air. Oleh karena itu pula maka volume pori komposit semen yang sebenarnya tidak dapat dilihat dari nilai porositasnya saja.

Nilai porositas contoh uji rata-rata sebagai akibat dari pengaruh faktor $B$ pada berbagai taraf persentase sekam padi dapat dilihat pada Gambar 2. Gambar 2 menunjukkan nilai porositas contoh uji rata-rata karena pengaruh faktor $B$ (persentase sekam padi) masing-masing adalah 31,7 dan 34,1 $\%$ yang terjadi pada persentase sekam padi B1 ( 30 $\%)$ dan B2 (40\%).

Hasil uji BNJ pada Tabel 2 mengenai pengaruh faktor $B$ (persentase sekam padi) terhadap porositas

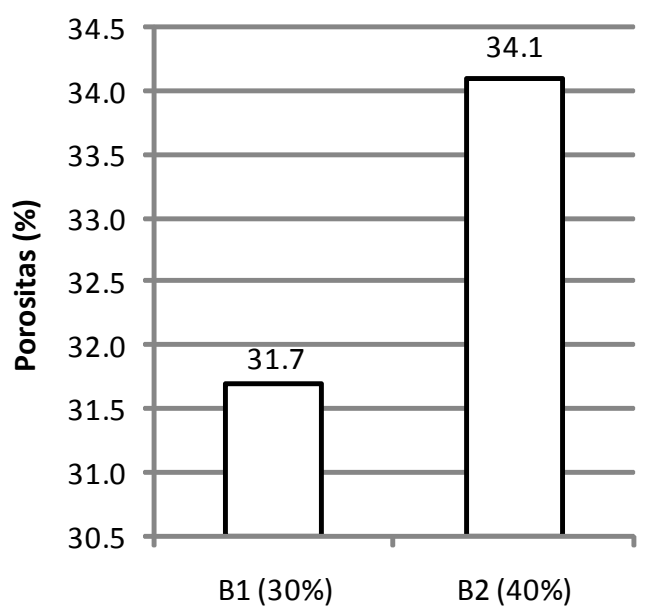

Persentasi Sekam Padi (\%)

Gambar 2. Pengaruh faktor B (persentase sekam padi) terhadap porositas 
menunjukkan bahwa nilai porositas contoh uji rata rata terendah sebesar $31,7 \%$ terjadi pada perlakuan persentase sekam padi $30 \%$ dan nilai porositas contoh uji rata rata tertinggi sebesar 34,1 $\%$ terjadi pada perlakuan persentase sekam padi $40 \%$. Tabel 2 menunjukkan pula bahwa perlakuan persentase sekam padi $40 \%$ berbeda nyata dengan perlakuan persentase sekam padi $30 \%$.

Perbedaan nilai porositas oleh faktor B (persentase sekam padi) dipengaruhi oleh porositas bahan sekam padidan pembentukan zona interfasial. Sekam padi digolongkan sebagai bahan yang sangat porous karena memiliki nilai porositas sebesar 79 $\%$. Penyerapan air akan menjadi lebih besar pada sekam padi karena tingginya nilai porositas sekam padi. Nilai porositas sekam padi yang sangat besar menyebabkan nilai porositas contoh uji menjadi lebih besar pula. Penambahan persentase sekam padi yang lebih banyak menyebabkan porositasnya akan menjadi semakin besar. Hal ini dapat dilihat pada porositas perlakuan persentase sekam padi 40 $\%$ (B2) yang lebih besar dari perlakuan persentase sekam padi $30 \%$ (B1).

Porositas yang semakin besar akibat pengaruh faktor sekam padi dapat pula disebabkan oleh banyaknya zona interfasial yang terbentuk. Agregat sekam padi dapat membentuk ruang kosong atau zona interfasial yang terjadi di antara permukaan sekam padi dan pasta campuran semen sehingga terjadi segregasi antara sekam padi dan pasta campuran semen. Gaya tarik molekul sekam padi dan pasta campuran semen atau gaya adhesi yang lemah karena sekam padi memiliki permukaan yang halus akan memisahkan sekam padi dengan pasta matriks semen. Pemisahan antara agregat sekam padi dengan pasta matriks semen akan memperbesar zona interfasial ini. Semakin besar persentase sekam padi maka semakin besar pula kemungkinan terjadinya zona interfasial sehingga porositas semakin besar.

Sekam padi yang memiliki porositas yang sangat tinggi akan cepat menyerap air dalam jumlah

Tabel 2. Uji BNJ pengaruh faktor B (persentase sekam padi) terhadap porositas (\%)

\begin{tabular}{|c|c|c|}
\hline B (\%) & $\begin{array}{l}\text { Porositas rata- } \\
\text { rata }(\%)\end{array}$ & BNJ $0,05=0,9$ \\
\hline 30 & 31,7 & a \\
\hline 40 & 34,1 & $b$ \\
\hline
\end{tabular}

yang banyak pada saat proses pencampuran bahan sehingga mengurangi kecepatan hidrasi semen. Jumlah air yang digunakan oleh semen untuk melakukan hidrasi semakin berkurang karena lebih banyak diserap oleh sekam padi. Jika air berkurang pada pasta semen maka suhu hidrasi menjadi rendah karena proses eksotermis tidak berlangsung sempurna. Reaksi C3S dan C2S menjadi sangat lambat untuk menghasilkan $\mathrm{CSH}$ dan $\mathrm{CH}$ karena jumlah air yang tidak cukup untuk melakukan reaksi.

Air yang diserap oleh sekam padi dapat digunakan kembali oleh C3S dan C2S tetapi membutuhkan waktu yang cukup lama sehingga pembentukan $\mathrm{CSH}$ dan $\mathrm{CH}$ yang seharusnya terjadi pada awal pencapuran bahan menjadi tertunda. Oleh karena pembentukan $\mathrm{CH}$ menjadi lambat maka pembentukan CSH sekunder juga akan terjadi pada waktu yang lama padahal CSH sekunder terbentuk untuk memperkecil atau menutup rongga pori. Semakin banyak jumlah sekam padi yang digunakan maka pembentukan $\mathrm{CSH}$ sekunder menjadi lebih lambat sehingga volume pori menjadi lebih besar.

Penyebaran butiran partikel agregat sekam padi yang tidak homogen atau merata pada pasta campuran semen dapat pula membentuk rongga rongga kosong di antara butiran partikel sekam padi. Peluang yang lebih besar untuk menghasilkan rongga kosong di antara butiran partikel sekam padi akan terjadi pada persentase sekam padi yang lebih besar mulai pada saat pencampuran bahan hingga proses hidrasi selesai. Jennings (1988) mengemukakan bahwa setiap jenis agregat memiliki tipe, ukuran, distribusi ukuran, dan tekstur permukaan yang sangat beragam yang berpengaruh terhadap mikrostruktur produk berbasis semen. Selanjutnya dijelaskan bahwa agregat yang berasal dari serat sangat susah menyebar secara merata dalam matriks campuran semen dan serat yang memiliki permukaan yang halus memiliki ikatan yang lebih lemah dengan semen dibandingkan dengan serat yang memiliki permukaan yang halus.

Pembentukan seluruh pori oleh pasta semen murni setelah proses hidrasi berlangsung hanya sekitar 5-6 \% dari volume pasta semen (Bertolini et al., 2004). Oleh karena itu kontribusi sekam padi sebagai agregat terhadap pembentukan volume pori total dalam penelitian ini sangat besar karena nilai porositas pada perlakuan persentase sekam padi 30 dan $40 \%$ sangat besar jumlahnya. 


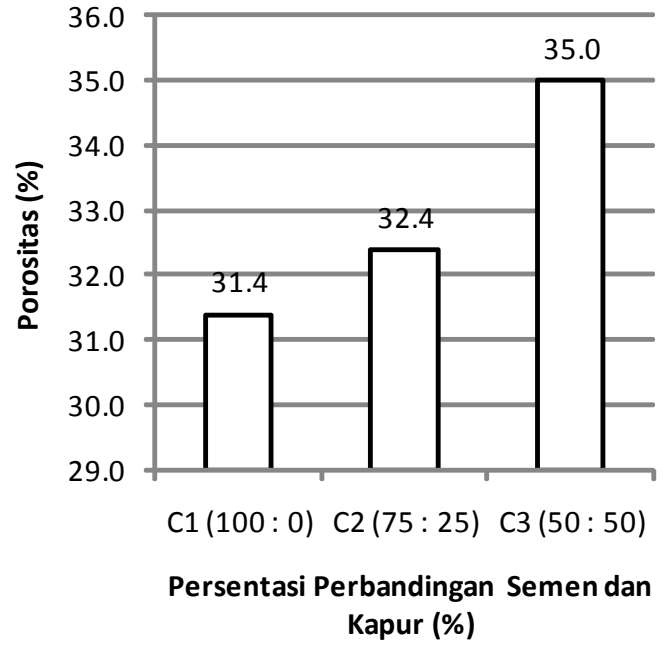

Gambar 3. Pengaruhfaktor $\mathrm{C}$ (perbandingan persentase semen dan kapur) terhadap porositas

Nilai porositas contoh uji rata-rata sebagai akibat dari pengaruh faktor $\mathrm{C}$ pada berbagai taraf perbandingan semen dan kapur dapat dilihat pada Gambar 3. Gambar 3 menunjukkan nilai porositas contoh uji rata- rata karena pengaruh faktor $\mathrm{C}$ (perbandingan semen dan kapur) masing-masing adalah 31,$4 ; 32,4$ dan $35,0 \%$ yang terjadi pada perbandingan persentase semen dan kapur $\mathrm{C} 1$ (100: 0), C2 (75: 25), dan (50:50).

Hasil uji BNJ pada Tabel 3 mengenai pengaruh faktor $C$ (perbandingan persentase semen dan kapur) terhadap porositas menunjukkan bahwa nilai porositas contoh uji rata rata terendah sebesar $31,4 \%$ terjadi pada perlakuan perbandingan persentase semen dan kapur 100:0 dan nilai kerapatan kering tanur contoh uji rata rata tertinggi sebesar $35,0 \%$ terjadi pada perlakuan perbandingan persentase semen dan kapur 50 : 50 . Table 3 menunjukkan pula bahwa perlakuan perbandingan persentase semen dan kapur 50 : 50 berbeda nyata dengan perlakuan perbandingan persentase semen dan kapur $75: 25$ dan $100: 0$.

Table 3. Uji BNJ pengaruh faktor C (perbandinga persentase semen dan kapur) terhadap porositas (\%)

\begin{tabular}{|c|c|c|}
\hline $\mathrm{C}(\%)$ & $\begin{array}{l}\text { Porositas rata- } \\
\text { rata }(\%)\end{array}$ & BNJ $0,05=0,007$ \\
\hline 100:00:00 & 0,191 & a \\
\hline $75: 25: 00$ & 0,199 & $b$ \\
\hline $50: 50: 00$ & 0,213 & $c$ \\
\hline
\end{tabular}

Demikian pula perlakuan perbandingan persentase semen dan kapur 75 : 25 berbeda nyata dengan perlakuan perbandingan persentase semen dan kapur $100: 0$.

Perbedaan nilai porositas oleh faktor $\mathrm{C}$ (perbandingan persentase semen dan kapur) dapat dijelaskan berdasarkan pembentukan pori akibat penambahan kapur selama proses hidrasi. Pori gel dan pori kapiler terjadi karena pembentukan $\mathrm{CSH}$, sedangkan zona interfasial terjadi karena pembentukan $\mathrm{CH}$ di sekitar permukaan agregat. Semakin banyak $\mathrm{CH}$ yang terbentuk maka peluang terbentuknya zona interfasial semakin besar. Jika zona interfasial ini saling berhubungan dengan pori gel atau pori kapiler maka gerakan air ke dalam zona interfasial akan lebih mudah sehingga nilai porositas akan bertambah.

Penambahan persentase kapur yang lebih besar pada perbandingan persentase semen dan kapur akan menyebabkan rasio Ca/Si semakin besar pada pasta semen. Rasio Ca/Si yang semakin besar akibat penambahan persentase kapur yang lebih banyak akan menghasilkan $\mathrm{CH}$ yang lebih banyak pada proses hidrasi pasta semen sehingga akan menghasilkan zona interfasial yang lebih banyak. Oleh karena itu penambahan persentase kapur yang semakin besar pada perbandingan persentase semen dan kapur C3 (50: 50) menghasilkan porositas yang paling besar dibandingkan dengan C2 (75 : 25) dan C1 (100: 0).

\section{KESIMPULAN}

Penambahan pozzolan abu sekam padi sebesar 20, 30 dan $40 \%$ dapat mengurangi porositas conblock ringan sekam padi. Nilai porositas terkecil yaitu $31,0 \%$ diperoleh pada penambahan abu sekam padi sebesar $20 \%$.

\section{DAFTAR PUSTAKA}

Bertolini, L., B. Elsener, P. Pedeferi and R. P. Polder. 2004. Corrosion of Steel in Concrete. WILEY-VCH Verlag GmbH \& Co. KGaA. Weinheim, Germany

Dakroury, A. El. and M.S. Gasser. 2008. Rice Husk Ash (RHA) as Cement Admixture for Immobilization of Liquid Radioactive Waste at Different Temperatures. Journal of Nuclear Materials. 381: 271- 277.

DTI. 2003. Rice Husk Ash Market Study. DTI/Pub URN 03/668. United Kingdom: Brozeoak Ltd (Contractor).

Freitag, S. A., A. R. Goguel and N. B. Milestone. 2003. Minimising the Risk of Damage to Concrete Guidance 
Notes and Recommended Practice (Second Edition) Technical Report 3 (TR 3). New Zaeland: Cement and Concrete Association.

Harsono, H. 2002. Pembuatan Silika Amorf dari Limbah Sekam Padi. Jurnal ILMU DASAR. 3 (2): 98 -103.

Kerenidis, K. 2007. Mitigating Alkali Silica Reaction in Concrete with Supplementary Cementing Materials When Used in Conjunction with Portland Cements Having Alkali Contents in Excess of 1.0\%. PCA R\&D Serial No. 3023. Skokie, Illinois, USA: Portland Cement Association

Lee, N. 2005. Alkali-Silica Reactivity in Concrete. New Zaeland: Branz Ltd.

Naik, T. R. 2005. Sustainability of Cement and Concrete Industries. Paper Presented and published at the Global Construction: Ultimate Concrete Opportunities, July 2005, Dundee, Scotland.

[NCMA] National Concrete Masonry Association. 2007. ASTM Specification for Concrete Masonry Unit. TEK 1-1E. National Concrete Masonry Association, Virginia, USA
Shihonara, Y. and N. Kohyama. 2004. Quantitative Analysis of Tridymite and Cristobalite Crystallized in Rice Husk Ash by Heating. Industrial Health. 42: 277- 285.

Singh, N. B., V. D. Singh, S. Rai, and S. Chaturvedi. 2002. Effect of lignosulfonate, calcium chloride and their mixture on the hydration of RHA-blended Portland cement. Cement and Concrete Research. 32: 387-392.

Ganesan, K., K. Rajagopal and K. Thangavel. 2008. Rice husk ash blended cement: Assessment of Optimal Level of Replacement for Strength and Permeability Properties of Concrete. Construction and Building Materials. 22 (8): $1675-1683$.

Gastaldini, A. L. G., G. C. Isaja, N. S. Gomes and J. E. K. Sperb. 2007. Chloride Penetration and Carbonation in Concrete with Rice Husk Ash and Chemical Activators. Cement \& Concrete Composites. 29: $176-180$.

Girard, J. 2006. Lightweight Concrete Mixes. USA: The Concrete Countertop Institute, LLC. 